\title{
On Both Sides of the Mediterranean: on Travelling and its Cultural Contexts
}

\author{
DOI: http://dx.doi.org/1 0.12775/LC.2019.002
}

ravel broadens the mind: this may be a hackneyed saying but it is always relevant and very fitting as the opening phrase of a book dedicated to travels. All the texts in this volume prove this saying true, and we shall let them speak for themselves. They certainly demonstrate the importance of travel as an element of every culture at every stage of its development.

Travel broadens the mind of people of all epochs and all regions. In this Preface, we shall focus on the paradigm of travel, construed in very broad terms, primarily in the Arab and Muslim culture. After all, travels to the Arab world and Arab travels, mainly to Europe, constitute the axis of the texts collected here. The co-author of this Preface entitled one of the texts, published a few years ago: Although we do not know each other, we have known each other for a long time (Dziekan 2012: 135-157). And this could be the summary of the outcomes of the trips made by Arabs to Europe and by Europeans to the Arab world. Travel should broaden the mind but does it really? Does it make people of different cultures get to know each other better? And if they get to know each other, do they make good use of it? At this point, Dear Reader, we encourage you to read the studies in this volume and find the answers to these questions by yourself.

There are various aspects of travel in Arab culture. The everlasting journey has been part of the Arab civilisation from its very beginning. In fact, this civilisation was founded by nomadic Bedouins who rarely stayed in one place for long. Old Arabic poetry is full of descriptions of journeys across the desert. Swift camels were ridden in search of water, to bring goods for the market, or on a pilgrimage to Mecca or another holy site. Thus, there was not only a practical, but also a religious aspect to travel. A typical old Arabic qasida is often a poem about travel, e.g. to a king or another ruler to whom a poet dedicates his poem.

Speaking of the world of Islam, it is worth noting that the Quran mentions business travels $(106,2-3)$ and recommends travelling for experience as well: "Travel through the land; then observe how was the end of the deniers" $(6,11)^{1}$. Without travel, there would be no Arab Bedouin civilisation, or at least it would be completely different. It should be stressed, however, that those were travels across the land. Although there were ports on

1 Quotations from the Quran according to The Quranic Arabic Corpus, http://corpus.quran.com [05.02.2018]. 
the Red Sea coast and the eastern coast of the Peninsula, travel by sea did not have a significant impact. The poet Al-A'šà became the proverbial pre-Muslim Arab traveller, but in their travels, ancient Arabs did not show a huge interest in the outside world, nor was the outside world interested in them even though either party was well aware of the existence of the other.

Another, religious aspect of travelling is embodied by the Prophet Muhammad whose profession of a merchant involved travelling; imitatio Muhammadi thus encouraged Muslims to travel. In one of the hadiths, the Prophet said: "Seek knowledge, even in China!", and acquiring knowledge in China obviously had to involve travelling. Therefore, fi talab al-'ilm travels 'in search of knowledge' - were popular in Arab/Muslim culture. With time, travels became a very important element in the transfer of knowledge in Islam.

A very important role in the development of mediaeval Muslim "tourism" was undoubtedly played by pilgrimages to Mecca; after all, every Muslim should visit that holy site at least once in his lifetime (Hammoudi 2005).

Various aspects of the road, closely linked with travel, appear in Arabic terminology in various fields with surprising frequency. Thus, sunna means 'road, path', etymologically; madhab (school of law, also: a religious faction) - 'road'; tarīqa - 'road'; nahw (grammar) 'designated trail', similarly to nahg (in the Maghreb this word is used to denote 'street'); šarì'a - 'path to the water' - the most common name for 'street' - šäri' originates from the same root. The entire life of an Arab/Muslim is infused with travel, or spiritual travel, one might say.

This has surely contributed to the development of Muslim travel literature - adab arrihlat - as part of geographic literature. What is interesting, however, is that Arabs travelled to the east, west or south mostly to gain knowledge. Usually, those travels were not aimed at exploration to be followed by conquest, which, on the other hand, was quite characteristic of travels made by Europeans. With time, however, the Arabs were becoming less willing to travel.

The first Arabic accounts of travels, preserved at least in fragments, date back to the second half of the $8^{\text {th }}$ century. Most of these texts were written on commission and did not attain a high literary value until the $10^{\text {th }}$ century. At that time, As-Sīräfĩ and Buzurg Ibn Šahriyār were also active ${ }^{2}$. The riḥla, meaning "travel", is a characteristic genre of Arabic travel literature, but it did not develop until later (the Andalusian Ibn Ğubayr, d. 1217, is often regarded as the creator of the genre). Its classical period occurred in the Western part of the Arab world, not the Eastern part, and its most outstanding example is Rihla by Ibn Batțūta $\left(14^{\text {th }} \text { c. }\right)^{3}$, referred to as the "Arab Marco Polo". It is also worth noting that they were travelling more or less at the same time, and their works complement each other from the perspective of geography. Marco Polo described areas that Ibn Batțūta did not reach, and a comprehensive reading of their texts (of course taking into account the obviously different perspectives: a Christian and a Muslim one) gives us a broad view of the world known to the Mediterranean civilisation of the time.

Alongside accounts of actual travels, the $a \bar{g} \bar{a} \bar{\prime}$ ' $i b$ literature of "miracles", where authors described non-existing seas, lands, people and other creatures, enjoyed huge popularity.

\footnotetext{
2 For a broader discussion of those people and their works, see Zaborski 1998.

3 English translation of selected fragments in Ibn Battuta 1926.
} 
While a twelfth-century Andalusian Abū Ḥāmid al-Ḡarnāțī (2006) holds primacy in this genre, The Wonders of Creation by Al-Qazwīin $\left(13^{\text {th }} \mathrm{c}\right.$. ) are the best example of this literature (Bieniek 2002). The tales of Sinbad the Sailor, better known in Europe, also belong to this kind of literature. Spiritual or fantastic travels, though not aimed at creating fiction pretending to be reality, are a separate topic, e.g. the "travel" by Ibn Šuhayd that is discussed in this book and can be compared with the immortal work by Dante. This illustrates the extraordinary capacity of the term "travel" in its cultural context.

Travel literature, both "fictionalised" and pure documentary works, became an important source for the belles lettres as well as the development of scientific geographical literature. From the cultural perspective, it was expanding the geographical range of Muslim civilisation and Arabic culture.

Similar travel-inspiring factors can be indicated in the case of European literature. Once Christianity became established in Europe, pilgrimages were the most important motivation for travel. These were pilgrimages to holy sites in Europe as well as, more importantly for us, travels to the East, to sites associated with the very origins of Christianity. Peregrinatio ad loca sancta by the nun Etheria from the $4^{\text {th }} \mathrm{c}$. is the oldest of such texts (Etheria 2006). In Eastern Christian literature, there were the so-called хождения (Daniel 2003). The main destination of those pilgrimages was, of course, Jerusalem, the mediaeval hub of our civilisation, as can be clearly seen on mediaeval maps (Hauziński 1997: 73-80).

Europeans travelled to the East and not only visited their destinations, i.e. the holy sites, but also met the local residents who represented a much higher level of civilisation, i.e. Arabs and other peoples of the Levant, often referred to collectively but mistakenly as “Turks". It should be noted that many descriptions of those travels were typical pilgrims' itineraries whose authors treated the local people almost as if they had been invisible. It was not until later that Europeans began to notice people in the Middle East as people, not merely as background for Christianity's holy sites. Old European literature also knows the concept of fictitious travel, resembling the Arabic 'ağ $\bar{a}$ 'ib. Probably the most famous work of this kind are The Travels of Sir John Mandeville (2006) that became a "hit" in sixteenthcentury Europe.

Along with the historical, social and political changes in the Mediterranean Basin, other types of travel accounts also appeared, describing diplomatic and typical commercial trips. Educational trips, in many aspects resembling the Muslim fi talab al-'ilm travels, became popular among Europeans, particularly those representing the upper classes. Accounts of those trips frequently contained some noteworthy descriptions and observations of the social and cultural life of the world described. The travel tradition in the Romantic period was the most important in the context of the Middle East because those travels became part of the cultural life in the spirit of "Orientalism". In this context, it is worth recalling Gérard de Nerval (1851) or, among Polish poets, Juliusz Słowacki (Przybylski 1982; Słowacki 2009). Travel was to give a direct taste of the East idealised in the unfortunate work One Thousand and One Nights translated by Galland. Interestingly enough, Arabic travel literature of that period is also quite rich albeit for different reasons. In the $19^{\text {th }}$ century, the Arabs wanted to discover Europe - not to use "occidental" motifs in literature, even though it could happen as well, but primarily to learn about the achievements of Western civilisation. It was a time when the Muslim Middle East stopped being a teacher and became a student. A comparison of the nineteenth-century Arabic and European travel texts shows totally differ- 
ent approaches. In Europe, it was the peak in the development of colonial ideology; hence a deeper insight into the Muslim Orient is frequently an introduction to Said's concept of "Orientalism" (Said 1978). The Arabs, on the other hand, wanted to learn something, sometimes expressing a naive admiration of technological progress. As the modern times show, such an attitude has not always served them well.

For many years, both real and spiritual travels have been the subject of research by scholars and scientists of all disciplines. Therefore, it is difficult to indicate in this short Preface all the important, or even just the most important aspects of the problem whose analysis requires an interdisciplinary approach at the interface of history, anthropology, geography and literary studies. This internal diversity is evidenced by the texts presented in this book and illustrating the topics signalled in this Preface.

Marek M. Dziekan, Magdalena Lewicka

\section{References}

Bieniek, Adam 2002. „Zakariyā’ Ibn Muhammad Ibn Maḥmūd al-Qazwīnī and his Works”, Folia Orientalia XXXVIII: 29-40.

Daniel 2003. Ihumena Daniela z ziemi ruskiej pielgrzymka do Ziemi Świętej (Relacja z początku XII wieku). Transl. by Krzysztof Pietkiewicz. Poznań: Wydawnictwo Poznańskie.

Dziekan, Marek M. 2012. „Unknown, and yet long known. On some episodes in the history of cross-cultural contacts between Central Europe and the Near East”. In: Robert Kusek, Joanna Sanetra-Szeliga (ed.). Czy Polska leży nad Morzem Śródziemnym? / Does Poland lie on the Mediterranean?. Kraków: Międzynarodowe Centrum Kultury.

Etheria 2006. Egeria's Travels. Transl. by J. Wilkinson. Oxford: Aris \& Phillips.

Al-Ḡarnātịi, Ḥāmid 2006. De Grenade à Bagdad. La relation de voyage d'Abū Hāmid al-Gharnātì (1080-1168) ou Al-mu'rib 'an ba'd 'adjā'ib al-Maghrib (Exposition claire de quelques merveilles de l'Occident). Traduction annotée de Jean-Charles Ducène. Paris: Harmattan.

Hammoudi, Abdellah 2005. Une Saison à la Mecque. Paris: Seuil.

Hauziński, Jerzy 1997. „Jerozolima: doczesna czy mistyczna stolica Regnum Davidicum średniowiecza”. In: Piotr Paszkiewicz, Tadeusz Zadrożny (ed.). Jerozolima w kulturze europejskiej. Warszawa: Instytut Sztuki PAN.

Ibn Battuta 1926. Ibn Battuta Travels in Asia and Africa (selections). Transl. by H.A.R. Gibb. London: Routledge.

The Quranic Arabic Corpus, http://corpus.quran.com [05.02.2018].

Mandeville, John 2006. The Travels of Sir John Mandeville. Dover Publications: Mineola NY.

Nerval, Gérard de 1851. Voyage en Orient. Paris: Charpentier.

Przybylski, Ryszard 1982. Podróż Juliusz Stowackiego na Wschód. Kraków: Wydawnictwo Literackie. Said, Edward 1978. Orientalism. New York: Pantheon Books.

Słowacki, Juliusz 2009. Album rysunkowe z podróży na Wschód. Wstęp i oprac. Ewa Grzęda. Wrocław: Ossolineum.

Zaborski, Andrzej 1998. Wspaniaty Świat Oceanu Indyjskiego Sulajmana Kupca, Abū Zajda as-Sìrāî̀ i Buzurga Ibn Šahrijāra. Od literatury faktu do przygody i fantastyki (IX-X w.). Kraków: Księgarnia Akademicka. 